\title{
Sustainable Development-Meaning and Imperatives for Orchard Farmers of Hilly Regions of Uttarakhand: A Case Study of Ramgarh Area of Uttarakhand, India
}

\author{
Karan Singh Khati \\ Department of Management Studies, Amrapali Institute, Haldwani, Uttarakhand, India \\ Email:karan_khati@yahoo.com
}

\section{Doi:10.5901/ajis.2013.v2n11p64}

Abstract

The idea of sustainable development has been prominently in discussions lately. The developed nations have observed high economic growth in the twentieth century and now the onus has been shifted to the developing nations, majorly the BRIC countries, to provide the large, ever-increasing population a decent level of living. The unscrupulous usage of natural resources earlier by developed nations and now by the developing nations has led to problematic social and ecological changes. This paper tries to explore the pressure of economic growth and the consequences at village level. The study, exploratory in nature, is based on the experiences of a small village (Ramgarh) in the hills of Uttarakhand in India. The area was famous for the orchards, prominently apple, but over the years has seen unprecedented construction of cottages: mostly owned by rich people from outside. It is worth mentioning, that these areas have limited employment opportunities and had high dependence on the local agricultural/horticultural production as source of income. The uncertainties of income have forced large-scale migration to other parts of the country. Consequently, the socio-cultural fabric is also getting fractured. The study is important because it is a situation faced by most of the sections of the society in the rural hinterland of the country.

Keywords: Sustainable development, economic growth, orchard farmers, migration.

\section{Introduction}

The quest of economic growth has raised many questions for every country. It is always accompanied with certain problems sometimes unique to the country and sometimes general faced every country The impact of the economic growth is felt by every individual of a country, with far reaching implications. The pressure of economic growth not only leads to the sectoral changes in the economy but also in socio-cultural environment. For economic growth, it is imperative to move from the labour intensive agricultural economy to the manufacturing and service based economy. This change is not always smooth and easy. The agricultural sector mostly employs the unskilled labour but the other sectors require some minimum level of skill. Unfortunately, the agricultural economy because of the labour intensiveness is highly inefficient.

The developed nations faced the question of effective and efficient labour utilization during their journey of economic growth. The developing nations are now facing the same questions albeit with a difference. The developed nations during the expansion of their economy had practically limitless access to the natural resources sourced from the third world countries, in addition to this the question of environmental degradation also was not prominent. They could have made numerous mistakes and learnt. Also, the industrialized nations had to make their own rules so there was no question of violation of rules. The question of effectiveness and efficiency only came later and because of the vast capital resources, they were able to use technology for greener business model. The case of developing nations is totally different. For these nations, the question of economic growth comes before sustainability, as a strong growth is required to support the growing population. Their needs are urgent and they do not have the technology or the resources think for or act on sustainable business model. But, the paradox is that they have to use their resources rather more judiciously, in comparison to the developed nations as they do not have the liberty of having vast resources. Thus, the developing nations have to be more proactive towards the sustainability dimension of development.

\subsection{Meaning of Sustainable Development.}

The concept of sustainable development came into light in 1987 with the publication of Our Common Future, which firmly established sustainable development as a critical component of international development (Sneddon et al, 2006). Since 
then there has been a lot of discussion and deliberation on the concept of sustainable development. The ever increasing population, specifically from the third world countries, its needs and wants need to be fulfilled. This requires high economic growth on continuous basis. As Datta (1997) has rightly pointed out that the Keynesian economics, which resulted due to the depression of 1930 is no longer as fruitful today as it was then and now we have to look further than the methods of industrial growth as the questions we are facing now for a sustainable economy are not being answered.

Thus, we have to move beyond the concept of economic-growth-only model to something which is more stable and long lasting. Thing on these lines World Commission on Environment and Development in 1987 defined sustainable development as:

Sustainable development is development that meets the needs of present without compromising the ability of future generation to meet their own needs.

Daly (1990), further clarifies that while growth is a quantitative increase in physical scale, development is a qualitative improvement. Thus, while growth is narrower in nature, development is holistic perspective and goes beyond the measurement of income based economic indicators.

The measurement of development can be divided into three sectors as three pillars of sustainable development (Dalal-Clayton and Bass, 2000):

\section{Economy: The creation of wealth and livelihoods \\ Society: elimination of poverty and improvement of quality of life \\ Environment: the enhancement of natural resources for future generations}

Thus, the development should not only lead to the increase in economic health of the people in general but should have positive impact on the overall wellbeing of the society and at the same time without degradation of the environment.

\subsection{India: Growth and Developmental perspectives}

Just after independence, the country was confronted with the question of economic growth as an independent nation. The initial impetus of growth was driven by the Nehruvian growth model. This model was capital intensive and resorts to manufacturing. He addressed the dams as temples of modern India. He realized that large scale industrialization was the only way of high economic growth. The country was facing large sc ale of deprivation because of the exploitation. So to meet the needs of such a large population high growth rate was pertinent. This model focused in creating the centers of industrial activities and movement of population from the agriculture to manufacturing. This led to migration of population. But, this model is criticized as it focuses on a smaller section of the society, and is alienated from the villages while the larger section of the society resides in the villages.

Other model of development is based on the philosophies of Gandhi, Father of Nation. He said:

India lives in its villages. If villages perish, India too perishes.

His contention was that, there can not be any development if the development models are not inclusive of the larger sections of the society, that is villages. Any development activity if devoid of the interests of the people living in the villages sill not be sustainable. He emphasized that we require labour intensive economic which can use the excessive labours we are bestowed with. Also, these labour intensive activities should be in harmony with the society and nature. But, this model tends to be criticized for slow growth rate and competitive disadvantage with the rest of the world. High labour costs render the products costlier.

Even after more than sixty years of independence, though the country has achieved high economic growth rate, the concept of development eludes us as the country is far down in the Human Development Index. There has been the quest for immediate economic results but the societal and environmental costs are looked over. There has been a question on the sustainability of these achievements.

\section{Area of Study}

Uttarakhand is located between $28^{\circ} 43^{\prime}-31^{\circ} 27^{\prime} \mathrm{N}$ latitudes and $77^{\circ} 34^{\prime}-81^{\circ} 02^{\prime} \mathrm{E}$ longitudes. The river Tons separates the state from Himachal Pradesh in the northwest, whereas the river Kali separates it from Nepal in the east. The greater Himalaya is the northern boundary of the state and is also the international border with China (Tibet). Foot-hills in the 
south are bound by Uttar Pradesh. Starting from the foot hills in the south, the state extends upto the snow-clad peaks of the Himadri making the Indo-Tibetan boundary. The region, being situated centrally in the long sweep of the Himalaya, forms a transitional zone between the per-humid eastern and the dry to sub-humid western Himalaya. In this region the human population is continually increasing and the region is experiencing major difficulties in sustaining its growing population on its squeezing environmental resources-land availability, forests and grasslands, water resource, etc. Much of the environmental resource degradation is governed by mountain specificities, viz., inaccessibility, fragility, marginality, diversity (heterogeneity), niche (natural suitability) and adaptability (human adaptation) apart from the growing population. They result in limited external linkages and replication of external experiences, slow pace of development, intraregional imbalances and underutilization of regional potential.

The population of the state primarily depends on agriculture for livelihood; about $70 \%$ of the population is engaged in agriculture. Out of total reported area, only $14.02 \%$ is under cultivation. More than $55.0 \%$ of the cultivated land in the State is rain-fed. The cropping intensity is $160.6 \%$. The landholdings are small and scattered. The average land holding is around 0.68 ha (that too is divided into many patches) in the hills and 1.77 ha in the plains. About $70 \%$ of hills population is engaged in agriculture. There is hardly any other major source of livelihood deriving from the secondary or tertiary sectors. These sectors are very poorly developed primarily because of inaccessibility and vulnerability of mountain regions. As a result, it does not provide sufficient income levels to the people. This subsistence nature, which leads to low incomes and unstable incomes, which in turn lead to a sizeable out-migration of male members that leads to only women headed families behind, and the role of women in the household economy becomes more important.

Crop yields in Uttarakhand are low and there is a lack of effective marketing infrastructure including all post-harvest activities such as collection of the farm produce from the fields, transportation to warehouse, storage, processing, packaging, access to potential markets, information about prices, and finally marketing the produce at a price that is most remunerative to the farmer. In addition, there is a lack of availability and accessibility to horticultural inputs and the knowledge/information about suitable and remunerative crops and scientific management practices is scanty. Limited credit facility to farmers, remains another big constraint.

The area of study, Ramgarh [ $\left.29.45^{\circ} \mathrm{N} 79.55^{\circ} \mathrm{E}\right]$ is a small hill station and tourist destination in Uttarakhand, India. With an average elevation of 1,518 metres (4,980 feet), the place is rich in orchards. Ramgarh is also known as the "Fruit Bowl of Kumaon" owing to its verdant orchards of Peach, Apricots, Pears \& Apples. It comprises two parts - Malla, located on an elevation and Talla, located downhill. An unobstructed view of the snow-capped ranges of the Himalayas can be seen from this place. The place was once the cantonment of the English army.

This area was chosen for study as it shows the conflict the locals witness almost everywhere in the hills of the state. The state has prominently only two occupational prospects if they do not want to get dislocated. One is agriculture and the other is tourism. Some areas are not tourism destinations so people do not have any choice but to stick with whatever agricultural activity they pursue. Given the areas where both the options are open people observe the key conflict of choosing between the two or harmonizing them. While agriculture is not very lucrative and can only be pursued for sustenance, tourism is a capital intensive activity and requires reaching out to the outer world which most of the villagers are not capable of. This area is witnessing this conflict for past many years and the outcomes of the choices people have taken are now visible. The area has large number of orchards and still a prime producer of fruits though the fruit production has decreased considerably, at the same time the quality of fruits has worsened. On the other hand, there has been an unprecedented growth in real estate. People from the planer areas come here for vacations, prominently in summers. Owing to the good climate and short distance from Delhi, the nearest metro, many rich people have bought permanent properties in the area. This caused a boom in the construction and the locals saw it an opportunity for gaining instant benefit by selling their lands, which was not very productive otherwise. Some of the locals who did have the capital took benefit of the situation by constructing hotels but such numbers are less.

Thus, the area is perfect to study the impact of multidimensional growth and developmental activities, the conflicting interests people face and the meaning they attach to it.

\section{Objective of the Study}

The study strives to explore the dynamics of growth and development in the specified area. Since the developmental activities are not restricted to the economic activities and affect practically every aspect of the human life, so the holistic understanding of the impact is needed. The study had following objectives:

1. To know the experiences of people in the changing environment.

2. To know the meaning they attach to the orchards and horticulture activities 
3. To know their outlook of the future

4. The meaning they attach to development

5. To know the difference they feel in their lives in past couple of decades

\section{Methodology}

The study is primarily conceptual in nature, thus, the exploratory research design is used. Primary data was collected through in-depth personal interview. Secondary data was collected from the government websites and other publications.

The interview was conducted on 20 respondents. People are generally skeptical of the outsiders, specifically, if it is related to questions regarding livelihood and occupation. So the respondents were identified on reference basis. The criteria of qualifying the respondents was that they have to be family heads, permanent residents of the area, having some land holding and had orchards at some point of time.

The interview was unstructured in nature with an objective explore various dimensions attached to the life of villagers in the couple of decades. The respondents were encouraged to share their feeling and outlook regarding orchard activities, real-estate activities, government interventions, cooperative movements, socio-cultural aspects, occupational changes, environmental changes etc.

\section{Findings and Discussions}

The data collected from the interviews and the consequent analysis of the data indicated towards some presumptive findings but some interesting findings as well.

\subsection{Socio-cultural aspect of orchard farming}

It was interesting to know that orchards were not just the source of income for these people but carried traditional cultural dimension. In most of the cases the orchards were the manifestation of closeness to nature and a hobby of the older generation. During those times the villages were self-sufficient and the requirements were much less. People grew the trees for the fruits for consumption and were shared with the others in the village. The surplus was sold to the traders from outside the village if approached but the farming was not keenly done for this economic activity. The trading was not the purpose but a fallout of the production done as a hobby.

\subsection{Lack of interest by the new generation}

Orchard farming is a labour and time intensive activity. The trees bore fruits only once a year but require the care throughout the year. The output is not consistent but cyclical in nature with some years of high productivity followed by some years of low productivity. The earlier generation had less aspirations and their life was restricted to the village only so for them orchards were a means of passing the time. They worked relentlessly on the farms. The new generation is has better exposure to the outside world and are more educated as well. For the youth the village life is tough and devoid of the luxuries of cities so they aspire for city life and are keen to leave villages and move to cities. For them working on the farms is not something they look forward to. In addition to this disinterest towards the orchards, they do not have the skills and knowhow of horticulture.

\subsection{Orchard Farming non-remunerative}

Due to various reasons, the orchards are non-remunerative for the farmers. The productivity is very much dependent on the climatic conditions. Apple crop is very sensitive to the changes in the climatic conditions. Over the past two decades there has been tremendous change in the climate. The average temperature has risen. The area witnessed frequent snowfall in earlier times now hardly gets any snowfall. The production has dwindled. The lack of proper marketing linkages often leads to non-remunerative production for the grower. The grower is dependent on the traders for taking the harvest to the nearest markets. Thus, the producers are at the mercy of the traders who take the benefits of their position. 
Most of the orchards have grown old and need to be replaced. But, the new orchards will take three to four years to bear fruits. Thus, there is a risk involved in the replacement. The whole exercise is capital and labour intensive but the actual results can only be seen after the gestation period. The growers are not in the position to take the risk.

\subsection{Helpful nature but not cooperative professionally}

Another interesting finding was that though the village people are very cooperative in nature and help each other in different village activities they are non-cooperative on professional and economic activities. Traditionally, people used to lend hands to other people in the villages for activities like working in the fields, marriages etc. and the same gesture was returned by others. The villages were self-sufficient so the economic aspects were never looked into. Thus, they never came together to form cooperatives to reap the benefits of the orchard farming. Since this is an economic activity so they tend to work separately and the middlemen and outsiders take benefit of it. Growers bargain separately for the produce and this has lead to disparity in the returns obtained by the growers. This has created a distance amongst the growers as they feel cheated by their own villagers.

\subsection{Lack of capital and business acumen}

The orchard farming is a capital intensive activity. Due to the changing climate there is inconsistency in the production and returns. Adopting the modern horticultural practices and the continuous monitoring of the orchards for different diseases and pests requires lot of capital. In earlier times, it was not such intensive as this was not the primary economic activity. But, now it is the source of livelihood for many and they don't have the capital required. For these people getting the finances from the government sources is also not easy due to numerous bureaucratic bottlenecks. This lack of capital has made most of the growers to rely on other sources for their livelihood. These simple hill people lack the business acumen and are thus cheated by the traders. There is lack of direct linkages with the markets and the traders rule the territory and these growers are the ultimate loosers. Because of the lack of the business acumen they have not been able to create any long term business relationships either among themselves or with the outside world.

\subsection{Economic compulsion and short-sightedness led to loss of property}

The life style has been influenced by the exposure to the city life and the movement of people from the cities has aspired them to get the amenities of cities. Some of the people in the area re well off and have better sources of income than others and thus improved life style. This has created a competition amongst the villager and many have relied on the easy way out of selling their land for meeting these requirements. That easy money has not lasted long and is spent on the consumables. Also, there has been an increase in the vices like excessive alcohol consumption. The people have thus lost the lands and still have no sources to support the new life style.

Some of the villagers had to sell their land to meet the financial requirement of maintaining the orchards since their was no other source of finance. So a part of the land was sold to the real estate builders and the immediate financial requirements were met.

\subsection{Influence of tourism and real estate boom}

The area because of the nice weather green orchards and the view of Himalayas was a prominent tourist destination. This attracted construction of hotels and cottages for stay and also ownership. Rich people from metros like Delhi started owning properties in the area. This gave boom to the real estate and the prices of land rose considerably. For the locals selling the land was an attractive option as the prices now were considerably more than what they used to be. But, the lack of bargaining power and non cooperation amongst themselves led them to get less for the land. Since they themselves didn't have the capital so they were not able to take the benefit of the tourism boom.

\subsection{Adverse impact on the ecology}

The real estate boom is without any planning and there has been lot of destruction of the already fragile ecological system of the area. The cottages and hotels have been constructed by cutting the hills and on steep slopes. There is no proper planning for the rain harvesting sewage disposal. There is a race to take maximum benefit as it lasts. The 
greenery has been traded with the real estate. Orchards have given place to buildings and the average temperature has increased. During rains most of the water flows away on the steep slopes and concrete covered lands and causes soil erosion. Since the water flows away so there is lesser replenishment of underground water resources. There is now scarcity of water during the summers and people have to look for water supply from far off places.

\subsection{Loss of cultural inheritance}

The non availability of income sources and loss of land had increase the pressure on people and caused migration to other part of the country even for menial jobs. Now since there is out migration in search of better opportunities so the aboriginal population has decreased. People are busy in their own activities/works that they have less time for others. The feeling of cooperation has decreased. The social gatherings have decreased in number and there is generational gap in the older generation and the younger ones. Due to large scale construction activities there is immigration of unskilled or semiskilled labourers from the other parts of the country. This is creating a disturbance in the cultural fabric of the area as the new generation due to various reasons is unaware of or least interested in this.

\subsection{Non uniform growth and lack of development}

The fruits of economic activities are not equitable distributed. Some villagers due to either their better financial conditions, or because of having land at strategically better places (on road head) received better dividends from the changing economic environment. Rest had to either sacrifice the opportunity or comprise and settle for lesser dividends. Many villagers sold their lands but were not able to use the money in judicious manner and spent it. So now they have neither the land nor the money. Many villagers now work as servants in the cottages that have come up on the land that they sold. Thus, there have been mixed stories or economic success.

\section{Conclusions}

The talk of economic growth is imperative as the population of the world is increasing the income has to be increased as well. The aspirations for a better life-style need a higher income to spend. For third world countries, the need of high economic growth is a matter of necessity to alleviate poverty. But the high economic growth has its own perils if the other two pillars of development: society and environment, are excluded. Any initiative of economic growth should be seen in the holistic perspective of sustainable development else, it would fail in long run.

The hill economy has many constraints and the developmental activities require a strong understanding of the interplay of socio-cultural, economic and ecological constraints. In addition to this, the limited resources people have and the conflicting business prospects if left for people to handle will lead to the exploitation of both the resources and the people. There needs to be government intervention and inclusion of local people in helping them to pursue the economic activities without damaging the socio-cultural and ecological fabric. A tailor-made, inclusive model of development needs to be developed for the such areas which is suitable for the specific conditions of the area.

\section{References:}

Dalal-Clayton, B, Bass, S. (2000), "National Strategies for sustainable Development: The Challenge Ahead", Environment Planning Issues No 25. International Institute for Environment and Development, London

Daly, H.E., (1990), "Towards some operational definitions of sustainable development", Ecological economics 2, p.1-6

Datta, A., (1997), For a quiet revolution, Papyrus, Calcutta

Sneddon, C., Howarth, R., \& Norgaard, R. (2006), "Sustainable development in the post -Brundtland World", Ecological economics, 57, 253-268

WCED (1987), "Our Common Future: The Brundtland report", Oxford University Press, Oxford, p 43.

http://en.wikipedia.org/wiki/Ramgarh,_Uttarakhand

http://nainital.nic.in/pages/display/189-ramgarh

http://dolr.nic.in/dolr/downloads/spsp/SPSP_Uttarakhand.pdf 